\title{
INTRODUCING MULTIDISCIPLINARY CREATIVE SUBTITLING IN TEACHING AUDIOVISUAL TRANSLATION: A CASE STUDY DURING THE PANDEMIC
}

\author{
Fitrotul Maulidiyah ${ }^{1 \bowtie}$ \\ ${ }^{1}$ Administrasi Niaga/D3 Bahasa Inggris, Politeknik Negeri Malang, Jl. Soekarno Hatta No. 9 Kota \\ Malang, Jawa Timur, 65141. \\ a-mail: fitrotulmaulidiyah@polinema.ac.id
}

\begin{abstract}
Several researches prove that subtitles clearly enhance the comprehension of the video. Standard subtitling practices have been regulated by the limitations of the field. The awareness of the need to develop subtitling practices along with new technologies has increased. Thus, subtitling practitioners have been constrained by the rules of the profession. On the contrary, recent research has revealed the possibility of performing creativity in subtitling, especially related to the restrictions of subtitling norms. More researches in audiovisual translation (AVT) have started to consider a multidisciplinary approach. The study implemented descriptive qualitative design. The study was conducted at Politeknik Negeri Malang and the participants were students of D3 Study Program in English who have completed their subtitling course. The results illustrated that students agreed that multidisciplinary creative subtitling helps them make the video more interesting. Additionally, it was identified that the need for learning the technology towards preparing the creative subtitling is high.
\end{abstract}

Keywords: subtitling, multidisciplinary, creative subtitling.

\begin{abstract}
Abstrak
Lebih dari 100 studi empiris membuktikan bahwa menulis takarir video meningkatkan pemahaman video. Praktik takarir standar telah lama diatur oleh beragam batasan. Terlepas dari meningkatnya kesadaran akan kebutuhan untuk mengembangkan praktik takarir menggunakan teknologi baru, praktisi takarir terus menghadapi kendala di lapangan dan norma profesi. Berbeda dengan pembatasan yang diberlakukan oleh norma-norma takarir, penelitian terbaru menunjukkan kemungkinan adanya kreativitas dalam penulisan takarir. Penelitian terbaru lebih lanjut dalam terjemahan audiovisual (AVT) telah mulai beralih ke pendekatan multidisiplin. Desain deskriptif kualitatif dianggap sebagai cara penyelidikan yang sesuai untuk penelitian ini. Penelitian dilakukan di Politeknik Negeri Malang dan pesertanya adalah mahasiswa Program Studi D3 Bahasa Inggris yang telah menyelesaikan mata kuliah Subtitling. Hasilnya menggambarkan bahwa mahasiswa setuju bahwa multidisciplinary creative subtitling membantu mereka membuat video lebih menarik. Selain itu, teridentifikasi bahwa kebutuhan untuk mempelajari teknologi untuk mempersiapkan takarir kreatif cukup tinggi.
\end{abstract}

Kata kunci: takarir, multidisiplin, takarir kreatif.

\section{Introduction}

There are several branches of multimedia, audio-visual, or screen translation. Some of the examples are subtitling, dubbing (also known as lip-sync), voice off, and live interpretation on television. Subtitling can be defined as a translation practice which includes presenting a written text, generally on the lower part of the screen. Subtitling also aspires to narrate the original dialogue of the speakers, along with the elements appearing in the image such as letters, inserts, graffiti, inscriptions, placards and the like, including the information that is contained on the soundtrack (Diaz Cintas \& Remael, 2007, Szarkowska, 2005).

Some audiovisual items, such as film, television, video, DVD, computer games, Internet, and live performances, use subtitling. It has some advantages over dubbing in that it is a low-cost, simple, bridging intercultural gap, and generally politically correct mode of screen translation (O'Connell, 2007). Subtitling introduces new challenges to conventional translation, such as the space and time limitations inherent in the subtitling process, visual norms, the 
transition of modes from speech to text, and other new challenges. One of them is its classification, which could serve as the foundation for any scholarly work on the topic. It is not an easy job to accomplish. The complexity stems not only from the sheer number of available forms, but also from the fact that it has a lot to do with technology rather than language alone.

All who watches videos benefits from subtitles (children, adolescents, college students, and adults). Many studies reveal that subtitling a video increases understanding, concentration, and memory. Subtitles are especially useful for people viewing videos in their second language, children and adults learning to read, and people who are deaf or hard of hearing (Gernsbacher, 2015).

The constraints of the field and the norms designed to respond to these constraints have long regulated standard subtitling activities. Indeed, the term "constrained translation" (Titford, 1982; Mayoral et al., 1998) was first applied to the field of audiovisual translation (AVT) to emphasize academics' preoccupation with these constraints. Despite the fact that television networks and subtitling firms have adapted these norms to their own needs, and despite increased understanding of the need to improve subtitling methods in tandem with emerging technology, subtitling practitioners continue to be constrained by the field's constraints and the profession's norms.

Subtitlers have generally failed to recognize the perspectives that could be gained by referring to audiovisual translation's parallel discipline: film studies, by staying centered on these norms. Though translators of poetry become poets and translators of plays become playwrights, film translators have largely been reduced to mere norm-obeying machines due to a failure to recognize the value of film studies. This newly developed subtitling practice, though, may be changing as a result of the renewed interest in creative or aesthetic subtitling practices.

\section{Theoretical Framework}

In comparison to the restrictions imposed by subtitling norms, recent research has returned to the possibility of subtitling innovation. The term "returned" refers to the roots of modern subtitling activities. Nornes (2007: 103) has emphasized the artistry involved in the creation of intertitles during the silent age of cinema. The creators of these intertitles used curved text lines, decorative borders, and basic animations in a manner close to that of a graphic designer.

Although Nornes (1999: 25-28) mentions the use of innovative linguistic and graphic subtitling styles in Japan from the 1930s to the present, subtitling styles in the Western world have changed little in the last eighty years. Without delving into the benefits or weaknesses of existing subtitling norms, rest assured that these conventions, which form the foundation for quality control and subtitling didactics, have now become indispensable.

According to Daz Cintas (2005), the increased flexibility provided by new technology (particularly in the home entertainment market) has resulted in a change in subtitling styles. These modifications concern dialogue techniques, the number of lines per subtitle, the use of colors, cumulative subtitles, and metatextual data. Nonetheless, these minor modifications to traditional subtitling procedures do not constitute a fundamental change in the subtitling mechanism. Admittedly, they are undoubtedly less imaginative than the first intertitles, which were developed nearly a century ago. Nornes' (1999) tirade on "corrupt" subtitling activities exemplifies this dissatisfaction. Nornes disapproves traditional subtitling methods due to their erroneous emphasis 
on invisibility, their domesticating translation techniques, and the abuse they inflict on the source language. $\mathrm{He}$ claims that this deceptive strategy pretends to get the target audience closer to the international while actually forcing the target culture on the source culture. Nornes' ideas have recently been used as the foundation for a "modern" form of creative or "aesthetic" subtitling (Foerster 2010: 85). These subtitles can appear in various positions or with unique typefaces on purpose; characters can move in front of them at times, and they can also become blurred as a result of the set design. Foerster advocates for more subtitling creativity, especially innovative subtitling, and emphasizes the importance of subtitles being personalized to individual films.

Latest study in audiovisual translation (AVT) has started to take a multidisciplinary approach. Chaume (2004), in addition, has suggested a film studies-based approach to audiovisual text analysis. He has brought attention to the vast number of semiotic codes in the film text by naming ten "signifying codes of cinematic language" pertaining to the cinema's acoustic and visual channels. Evidently, only one of Chaume's ten codes is concerned with linguistic problems, and even within this code, Chaume is swift to point out that translational difficulties, such as wordplay and culturally specific artifacts, are not exclusive to audiovisual texts. The transition from written script to 'prefabricated orality' is, in reality, the most challenging linguistic obstacle for the film translator.

The focus on the various acoustic and visual "signifying codes" that comprise each audiovisual text may thus be viewed as a compelling justification for the introduction of a creative subtitling practice. AVT researchers have not been able to fulfill the requirements of many other levels of meaning in film text with their reliance on the linguistic code for far too long. Thus, a creative subtitling technique will completely meet the communicative needs of each film text by establishing a very multidisciplinary approach to audiovisual translation.

\section{Research Methodology}

A descriptive qualitative design is considered as a suitable method of research in this study, which attempts to let students understand the theory and practice of multidisciplinary subtitling in their subtitling class. This study applies the features of the above design to provide an overall and comprehensive explanation of the interest in natural environments without manipulation (Gay et al., 1976; McMillan \& Schumacher, 1993; Bodgan \& Biklen, 2007).

This study is going to be conducted in Politeknik Negeri Malang which is located on J1. Soekarno Hatta No. 9 Kota Malang 65141. This university is taken as the setting of the research because the researcher has the access to the students. Furthermore, this university is chosen because the major courses in English department at Politeknik Negeri Malang are translation and hospitality industry. Students are already familiar with translation subjects because they are provided with several translation courses including subtitling, in particular. They have a six-hour meeting of subtitling course every week in a computer laboratory equipped with subtitle editing programs. The research subjects are students of the fourth semester because subtitling course is offered in the fourth semester.

Questionnaires and observation are the instruments adopted in this study. The respondents are students who have taken Subtitling course. The respondents are 25 students from 2B in D3 Study Program in English for Translation and Hospitality Industry, Politeknik Negeri Malang. There are 10 questions in the questionnaires related to translation competence, linguistic competence, 
pragmatic competence, and technical skills related to subtitling skills. The observation was carried out during the Subtitling course when the students were introduced with multidisciplinary creative subtitling.

\section{Results and Discussion}

Results of the study revealed that students strongly agreed that subtitles are important for movies/videos (97\%). This is proven by the results of the questionnaires related to translation competence. The other aspects of translation competences also revealed that students strongly agreed that subtitles help audiences understand scenes in the video being watched $(96 \%)$. The last aspect in translation competence is whether or not the subtitles must be implemented based on the principles of audiovisual translation. The responses illustrated that $90 \%$ of the respondents strongly agreed that audiovisual translation principles must be implemented. The average percentage for translation competence is $94 \%$.

The second category which was included in the questionnaires is related to linguistic competence. According to $89 \%$ of the respondents, Subtitles which are considered to be creative subtitles are more fun to read. Furthermore, $84 \%$ of the respondents stated that the creative subtitling positioning adds the aesthetic element of the movie. The last item in the questionnaires is related to the subtitle positioning. The audience gets a general interpretation of the situation and the conversation, as opposed to word-for-word understanding of each subtitle, according to $87 \%$ of respondents.

The third category is related to pragmatic competence. There are two items in this category. The first item is about creative subtitling, allowing the virtues (not restrictions) of this type of translation to be seen more positively. It was revealed that $88 \%$ of the respondents strongly agreed with this statement. The second item is that a creative subtitling technique will completely meet any film text's communications needs in which $86 \%$ of the respondents strongly agreed with this statement.

The last category is related to technical skills. The first result of this category revealed that $93 \%$ of the respondents agreed that students need to learn this multidisciplinary subtitling to deepen their understanding about subtitling. Moreover, $95 \%$ of the respondents also agreed that these multidisciplinary creative subtitles need other aspects outside translation to learn such as editing and video editing.

From the above explanation, it could be interpreted that most of the students showed their interests in learning this newly developed technique in subtitling. Only very few students are neutral in responding the questionnaires especially when it comes to the linguistic competence. Linguistic competence deals with the new form of this creative subtitling and students have not yet mastered this technique. Therefore, they probably have no idea what they will be dealing with. However, they did not show reluctant behavior when being asked about the importance of these technical skills related to creative subtitling.

Learning creative subtitling will require students to master not only translation competence but also technical skills especially related to technology. During the pandemic, it is harder to introduce them with this technology because most of the students are constrained with the equipment (lack of compatible computers and software). This is in line with the results of the questionnaires and observation which illustrated that $94 \%$ of the respondents strongly agreed that both translation and technical skills must go along and be mastered at the same time. Students must improve the competence related to linguistics and pragmatics as 
they are considered as means to understand the whole meaning which is going to be delivered to the audiences.

\section{Conclusion}

Based on the study conducted, it could be concluded that in audiovisual translation, and particularly in creative subtitling, it is necessary to take a multidisciplinary approach. According to Johnston's suggestion, the need for multidisciplinary research between film studies and audiovisual translation appears to be greater with regard to film practice than with translation theory. Academics such as Nornes $(1999,2007)$ and Chaume (2004) have already undertaken initial examples of such work. On the basis of these research work, it could be attempted to adopt a multidisciplinary approach to creative subtitling. This approach draws on the aesthetic qualities of established creativity subtitles, including the structure, characterization and philosophy of the film editing, in film texts as well as concepts of film studies. On the bases of these ideas, the development of creative subtitling practice (in specific, unique tones, forms, styles, specific effects and positions) may be recommended (not guidelines, norms or conventions). A genuinely multidisciplinary approach to creative subtitling involves more research in other relevant fields, including visual design and, in particular, video graphics and designing film titles, as mentioned earlier in this article. Moreover, it will soon be important to examine the reception of these subtiles, using techniques such as questionnaires and eye tracking software, in order to learn how they are perceived and the cognitive and affective answers that can be achieved, having learned the practice of creative subtitling. This idea is supported with the results of the questionnaires from the respondents who stated that translation competence (94\%) and technical skills (94\%) must be acquired by the students who would like to practice the multidisciplinary creative subtitling. In addition, linguistic and pragmatic competence must also be improved as they are inseparable elements too in the multidisciplinary creative subtitling $(87 \%)$. The art of creative subtitles therefore offers exciting potential approaches for audiovisual translation multidisciplinary practically and theoretically.

\section{References}

Chaume, F. (2004). Film studies and translation studies: Two disciplines at stake in audiovisual translation. Meta: journal des traducteurs/Meta: Translators' Journal, 49(1), 12-24.

Foerster, A. (2010). Towards a creative approach in subtitling: a case study. In New Insights into Audiovisual Translation and Media Accessibility (pp. 81-98). Brill Rodopi.

Gay, L. R., Mills, G. E., \& Airasian, P. W. (1976). Educational research: Competencies for analysis and application. Columbus, $\mathrm{OH}$ : Merrill.

Gernsbacher, M. A. (2015). Video captions benefit everyone. Policy insights from the behavioral and brain sciences, 2(1), 195-202.

Mayoral Asensio, Roberto; Dorothy Kelly \& Natividad Gallardo. (1988) "The concept of constrained translation: non-linguistic perspectives of translation." Meta 33:3. pp. 356-67.

Nornes, A. M. (1999). For an abusive subtitling. Film quarterly, 52(3), 17-34.

Nornes, M. (2007). Cinema babel: Translating global cinema. U of Minnesota Press.

O'Connell, E. (2007). Translation and minority language media: Potential 
and problems: An Irish Titford, C. (1982). Sub-titling: perspective. MULTILINGUAL MATTERS, 138, 212.

Schumacher, S., \& McMillan, J. H. (1993). Research in education: A conceptual introduction. New Yark, NY: HarperCollins College.

Szarkowska, A. (2005). The power of film translation. Translation journal, 9(2), 2005. constrained translation. Lebende Sprachen. Zeitschrift für Fremde Sprachen in Wissenschaft und Praxis Berlin, 27(3), 113-116.

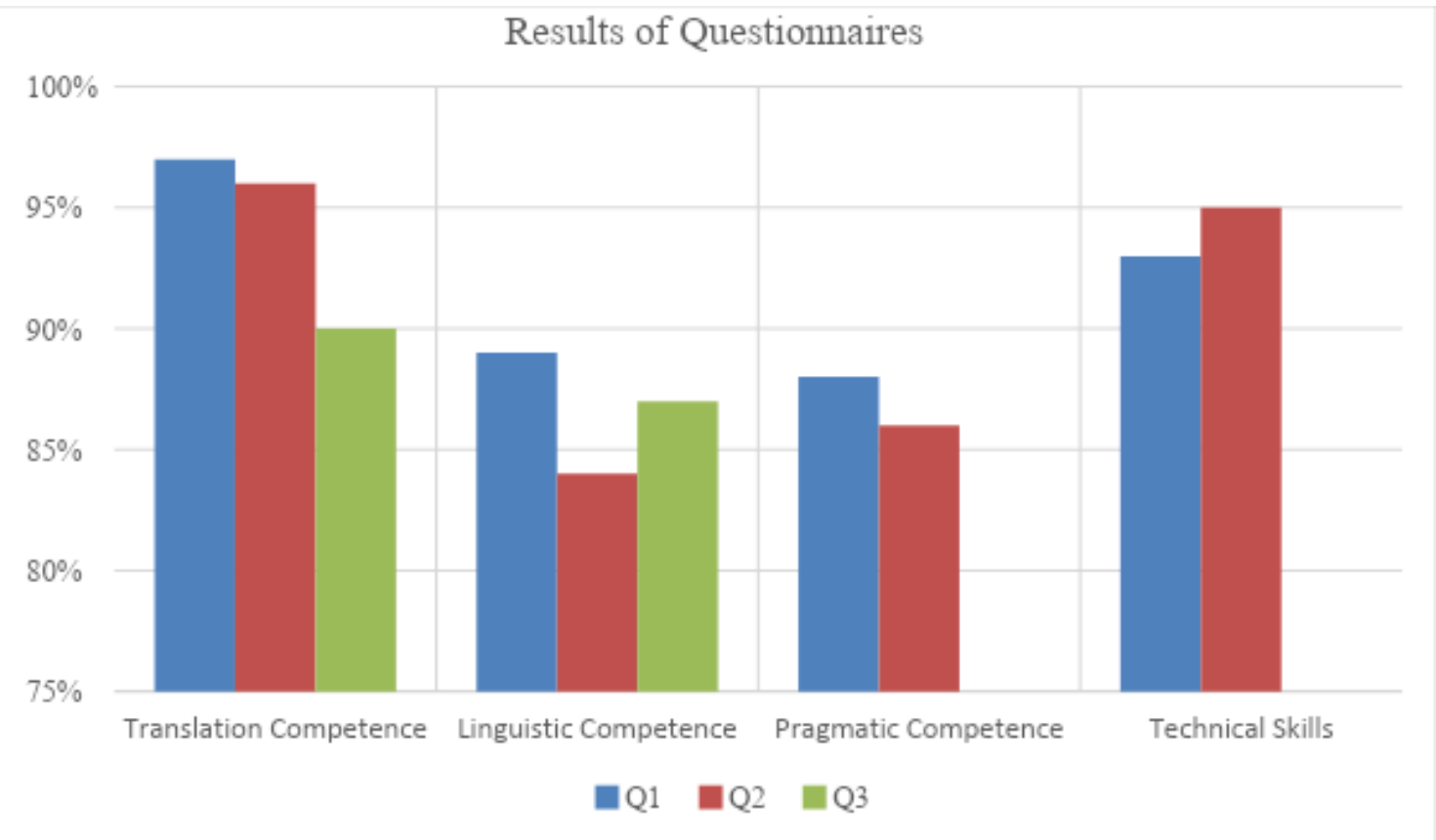

Figure 1. Results of the Questionnaires 